\title{
MERMAID ALLUSIONS AND STAR PROMOTION IN THE GREEK VIDEO-FILM GORGONA (1987)
}

[Received June 13th 2021; accepted August 12th 2021 - 10.21463/shima.143]

\section{Panayiota Mini}

\author{
University of Crete \& Institute for Mediterranean Studies, Foundation for \\ Research and Technology - Hellas <mini@uoc.gr>
}

\begin{abstract}
This article examines the first Greek film to give a central role to the concept of the mermaid: Georges Skalenakis' 1987 direct-to-video feature Gorgona ('Mermaid'). Although actually concerning an all-human female, Gorgona attaches to her many traits of both the internationally common half-fish/half-woman creature (known in Greek as

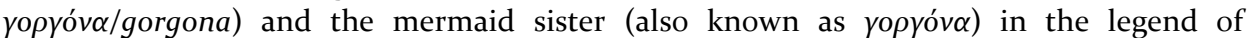
Alexander the Great. The article identifies the video-film's allusions to these fishtailed figures and argues that the film produced an updated mermaid image that responded to other national and foreign audiovisual conceptions of the mermaid of the 1980 s and enriched the star persona of its female lead, Eleni Filini, with a mythic quality and national symbolism.
\end{abstract}

KEYWORDS: Gorgona, mermaids, Greek 1980s' video production, Eleni Filini

\section{Introduction}

The modern Greek term closest to mermaid is yopyóva/gorgona, ${ }^{1}$ which encompasses the notions of the fishtailed females common in both western and global folklore and cultural media. Although this modern Greek term alludes to the ancient Gorgons - the three

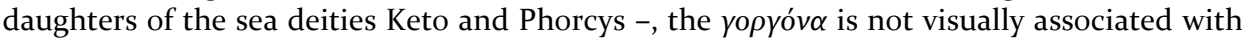
them; the ancient Gorgons were most often described as women with snakes for hair, tusks, wings, a terrifying gaze, and no fishtail (Syropoulos, 2018: 27-38). This is not to suggest that fishtailed creatures were unknown in ancient Greek mythology. On the contrary, the most famous was Scylla, the "twelve-footed, six-headed, anthropophagous monster" in Homer's Odyssey that on visual artefacts took the shape of a "beautiful halffemale and half-fish hybrid" with dog heads usually attached to her waist (Hopman, 2012: 9, 92). ${ }^{2}$ In its turn, Scylla's iconographic fishtailed component linked her to the earlier merman figure, often featured in archaic art (ibid: 97). ${ }^{3}$

\footnotetext{
${ }^{1}$ Alternate Greek and standard Western alphabet renditions of the same word.

${ }^{2}$ As Hopman (2012: 12) explains, like the names (and symbols) of other ancient monsters, that of Scylla was not associated with a fixed mental picture but could evoke different images.

${ }^{3}$ Anonymous mermen appear in Greek mythology as early as the 7th Century BCE. In the 6th Century BCE, named mermen, including Halios geron ("The old man of the sea"), Nereus, and Triton, are some of Heracles' marine adversaries (Hopman, 2012: 97).
}

Shima <www.shimajournal.org $>$ ISSN: 1834-6057 


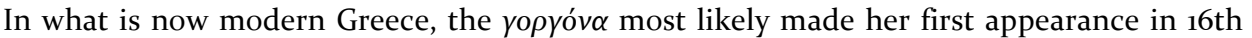
Century Venetian-occupied Crete (Zora, 1960: 345). Some scholars have seen a connection between this figure, on the one hand, and the ancient Gorgons, the Scylla, and other mythological sea creatures (e.g., the dangerous sweet-voiced sirens), on the other, suggesting a continuum in Greek civilisation. A less ethnocentric understanding of the

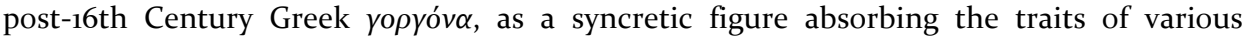

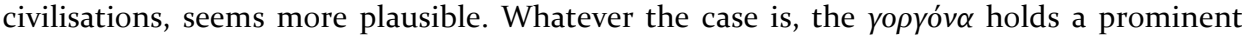
role in Greece's modern culture and art. Since the 17th Century she has inspired many folk and artistic creations. With one or two tails, sometimes holding a miniature boat, she has been depicted in embroideries, furniture decorations, the walls of houses and taverns (Politis, 1878: 261; Zora, 1960: 331; Kounenaki, 2001: 3) and in the works of major artists, including Greece's most famous folk painter Theofilos (c.1870-1934), novelist Stratis Myrivilis (1890-1969), and Nobel Laureates for poetry Giorgos Seferis (1900-1971) and Odysseas Elytis (1911-1996) (Chatzidakis, 2001).

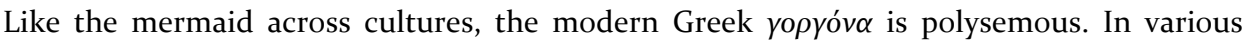
parts of Greece, her name has been used to mean different, even opposing female types, ranging from a beautiful and sweet-voiced girl to an evil and cursed woman (Politis, 1878: 262; Kamilaki, 2001). In folktales she may be the hero's helper or a murderer (Adikimenaki, 2004; Triantafyllou, 2020: 334-342). Predominantly, though, her figure has had national significance, primarily due to her legendary connection to Alexander the Great (Zora, 1960: 352). According to this legend, popular since the late 17th Century, Alexander the Great had a sister, who accidently deprived him of his water of immortality and was then turned into a mermaid. ${ }^{4}$ From that moment on, she wanders over the sea, asking every sailor, "Is King Alexander alive?" If the sailor gives the desired answer, "He lives and reigns and conquers the world," she happily calms the sea and lets the ship sail away safely. Otherwise, she angrily conjures up a storm that sinks the ship with its crew. ${ }^{5}$

This folk legend found its most famous Greek literary rendition in Andreas Karkavitsas' (1865-1922) 1899 short story 'I Gorgona' ('The Mermaid'), which brought the myth's nationalist connotations to the fore by linking Alexander with centuries of the Greek spirit and with the collective memory of his conquests in the East. According to Karkavitsas' sailor/narrator, who encountered the $\gamma$ o $\rho$ óv $\alpha$, when asking him if King Alexander was still alive, she "did not ask of course about the perishable body but about the memory of her master" (1994: 163); ${ }^{6}$ when he said that Alexander was indeed still alive, a martial song floated on the wind "as if the Macedonian army was right now returning from the countries of the Ganges and the Euphrates" (ibid: 164). This short story has been anthologised in

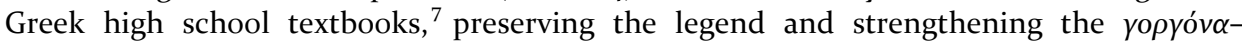
Alexander the Great-Greece correlation in Greek culture. Many other works in the Greek literary canon have suggested this correlation. Myrivilis, for example, who titled his 1955 novel I Panagia i Gorgona ('The Mermaid Madonna') after such a peculiar Christian icon

\footnotetext{
${ }^{4}$ In different variations on the legend, Alexander's sister either drinks or pours the water of immortality and turns into a mermaid cursed by her brother or punishes herself out of guilt and sorrow.

${ }^{5}$ For a popularised rendition of this legend in English, see Mitakidou, Manna, and Kanatsouli (2002: 93-95). A Cretan variation is included in Bacchilega and Brown (2019: 64-65).

${ }^{6}$ All translations from Greek into English in this essay are the author's unless otherwise noted.

${ }^{7}$ According to a survey (Aggelopoulos, 2014: 46), between 1913 and 2003 it was anthologised in eight Greek high school textbooks.
}

Shima Volume 15 Number 22021 
(and a chapel) in his native island of Lesvos, described this iconic deity as encompassing in the most amazing way "all the epochs and all the meaning of the [Greek] race; a race that lives and struggles with the elements and with the storms, half on the earth and half of it in the sea, with the plowshare and the keel" (Myrivilis, 1987: 16). Seferis, who placed the image

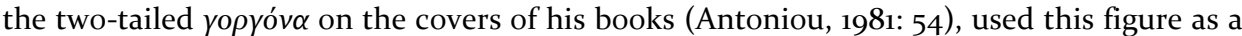
symbol of the eternal feminine, poetry, craftsmanship, and folk tradition (Antoniou, 1981: 53-71; Tentorio, 2013) but, perhaps above all, of the Greek spirit and sorrow concerning

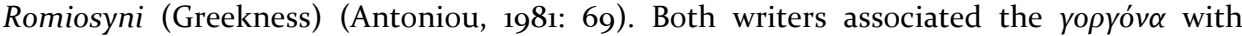
Alexander's legend (Myrivilis, 1987: 172-173; Antoniou, 1981: 60, 64-65, 70-71; 144).

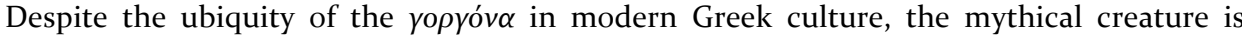
conspicuously absent in this country's cinema. In about 1,400 films produced between the

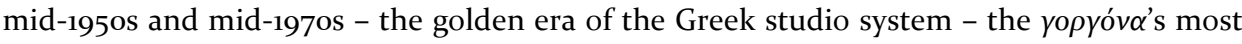
notable contribution has been lending her name to the title of a popular musical set on a Greek island, Gorgones kai magkes ('Mermaids and Rascals', also known as 'Mermaids for Love', 1968, Giannis Dalianidis), and furnishing it with two additional references. One of

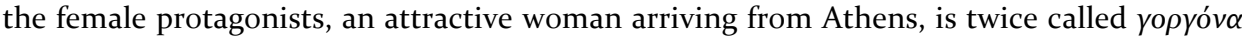
because of the spell she casts on men, while in the film's extravagant concluding number, with the protagonists now on an Athenian stage show, the background female dancers are dressed in bright bikini tops and short skirts resembling fishtails. In the remaining films

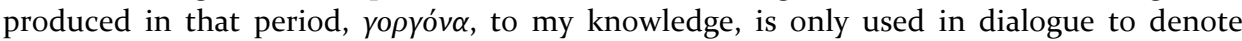
attractive girls. Two factors can explain the absence of the fictional mermaid in the films of that time. One is that there was no fantasy genre in Greek cinema. The other factor is that

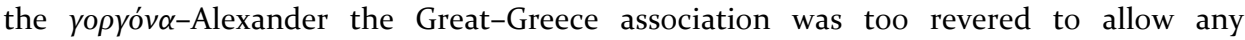
depiction of mermaids in a modern film context unrelated to Alexander (whose legend has never been depicted in Greek cinema). Gorgones kai magkes reveals, almost symbolically, the way in which mermaids could be incorporated into popular Greek cinema: as a decorative, folkish element denoting Greece and beautiful women and embedded into a western-style show for mass consumption - just as the title Gorgones kai magkes adapts the title of the American musical film Guys and Dolls (1955, Joseph L. Mankiewicz - released in Greece as Magkes kai koukles ['Rascals and Dolls']), at a time (the late 196os) when the return to tradition was a staple in Greek popular and social discourse. ${ }^{8}$

It was after the decline of Greece's studio system, in the 1980s - the heyday of direct-tovideo production for home rentals - that such a production gave a central role to the mermaid concept. In 1987, Giorgos Skalenakis (1926-2014), an accomplished director of popular films, shot Gorgona, written by Lefteris Kaponis (1947-2017) and featuring videofilm industry's foremost female star, Eleni Filini. Like previous Greek films, Gorgona does not concern a half-fish, half-woman creature. The female protagonist, to whom the title refers, is a flesh and blood woman. Yet, the 1987 video-film draws on many motifs globally associated with mermaids. In addition, it explicitly cites the Alexander legend. At a time when mermaids became "strikingly prominent in international popular culture" (Hayward, 2018c: 1), Skalenakis' Gorgona used widely known traits of the mermaid and the legend about Alexander's sister, revising them and combining them with the characteristics of Greek video-film art's ideal woman, as personified by Filini. In this way, Gorgona responded to other national and foreign audiovisual conceptions of the mermaid of the 1980 s, while enriching the star image of Filini with mythic quality and national symbolism.

\footnotetext{
${ }^{8}$ For further information on the use of folk elements in Gorgones kai magkes, see Papadimitriou (2006: chapter 6).
} 


\section{Mermaid references in Gorgona}

In Gorgona, Filini plays Marina Doxiadi, an archaeologist, who has just graduated from the University of Athens. While traveling to her house on an unnamed island for her summer vacation, Marina meets an attractive man, who introduces himself as Petros, a psychology professor. The man, whose real name later becomes known to Marina, is really an antiquity smuggler, the boyfriend of Marina's Athens roommate. Petros plans to rob the remnants of an underwater ancient town located by Marina's late father. To win Marina's trust, Petros pretends to fall in love with her. She then shows him where the town had been located. While Petros brings the ancient artefacts to the surface, his accomplice tries to drown him, but Marina saves him and helps him flee the island and arrest. For the next three years, Marina remains on the island, postponing her return to Athens and waiting for the moment that she would feel that Petros is ready to be with her. Meanwhile, Petros, who has indeed fallen for Marina, is in Athens working as an honest seller of ancient replicas, keeps visiting the University of Athens to find out whether Marina has returned to receive her diploma, and spends his nights in a bar, drinking and thinking of her. Eventually, Marina returns to Athens and the couple reunites outside the university building.

Among the about 1,10o direct-to-video Greek productions made between 1985 and 1990 (Kassaveti, 2014; Kassaveti, 2017: 57), Gorgona could be considered a quality work. When most of these productions were shot in "small, distasteful apartments" (Kassaveti, 2017: 70), urban plazas, discos, hotels, sea cruises, and coastal continental areas close to Athens (Kassaveti, 2014: 25, 45-47), Gorgona was partially shot on Poros, a charming isle in the Saronic Gulf. ${ }^{9}$ Despite some plot gaps and a loosely connected erotic love scene between Marina's roommate and Petros' accomplice, Gorgona's storyline is more tightly structured than in most Greek video products, which often unfold as a series of scattered episodes. And signs of frugality notwithstanding, Gorgona's production value is above that of the average video-film, as seen in the unprecedented use of underwater shooting in Greek video production (Anonymous, 1987). The relatively high quality of Gorgona should also be attributed to the expertise of director Skalenakis, screenwriter Kaponis, and composer Vaggelis Pitsiladis (known since the late 1960 os for his melodic works). ${ }^{10}$ Moreover, unlike most male protagonists of other Filini video-films, who are either emerging or unknown young actors or populist comedians of an older generation, the male protagonist of Gorgona, Faidon Georgitsis (1939-2019), is a famous actor of the Greek cinema of the 1960s and 1970s, no other than the protagonist of Gorgones kai magkes, who, while approaching his fifties in Gorgona, retains some of his charm and star quality.

Allusions aside, Skalenakis' video-film makes two direct visual references to the fictional creature. In the opening credit sequence, the film's title appears over an image of Marina swimming underwater, with one of the gamma characters in the word yo $\rho$ óv $\alpha$ replaced with a mermaid (Figure 1). Later, as Marina appears suggestively posed in an isolated idyllic

\footnotetext{
${ }^{9}$ For the shooting locations of Gorgona, as well as photographs of the filming, see Anonymous (1987).

${ }^{10}$ Many of Pitsiladis' albums of the 1960 and 1970 s featured maritime, summertime or Greek themes e.g., Korallia ('Corals', 1968), Neraides ('Fairies', 1969), To naftiko mas ('Our navy', 1970), Thalassaki mou ('My little sea', 1972), Summer nights in Greece (1974), Greek sounds (1977) and Oi theoi tou Olympou ('The Olympian Gods', 1977). During the 1980s, Pitsiladis mostly prepared soundtracks for TV series and video-films. In an interview in 2014, he mentioned the poor quality of the 1980 os video-films but noted that he had composed the soundtracks for some good ones, including those starring Filini (Pavlikianis, 2014).
} 


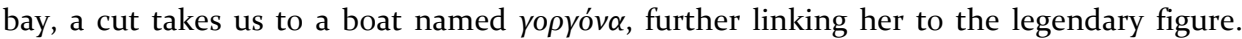
These visual references are accompanied by plenty of images and situations that bring to mind the woman with the tail of a fish. In the opening credit sequence, which unrolls over a (later) scene in the video-film, Marina and Petros romantically wade in the sea, with Marina, in a light white dress, leading Petros by the hand and looking back at him; the shot freezes at the moment when Marina is up to her thighs in water like a mermaid. Throughout the video-film, Marina (whose name derives from the Latin word for 'marine') is often shown in or by the sea. She reclines alluringly on rocks or onshore, caresses her long, wet hair and lets it flow down her back, and poses for the camera (Figures 2, 3, 4), thus evoking images of mermaids (Hayward, 2017).

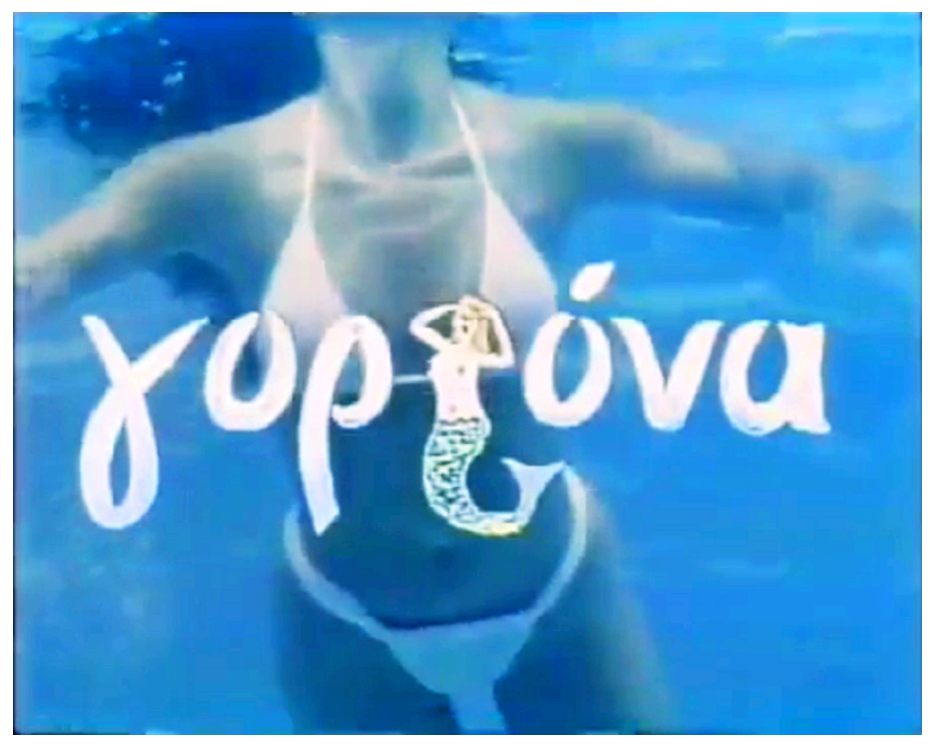

Figure 1 - Still from title sequence from Gorgona (1987).

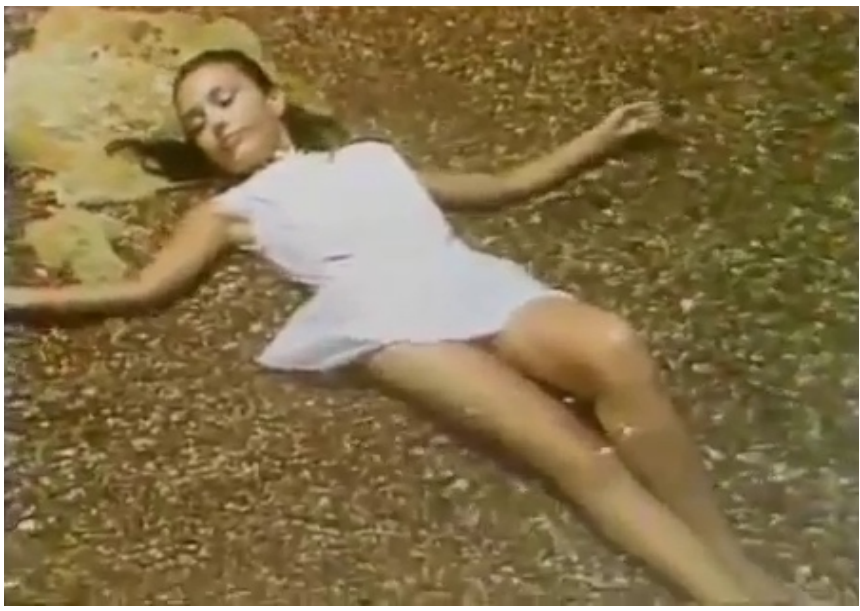

Figure 2 - Still from Gorgona (1987). 


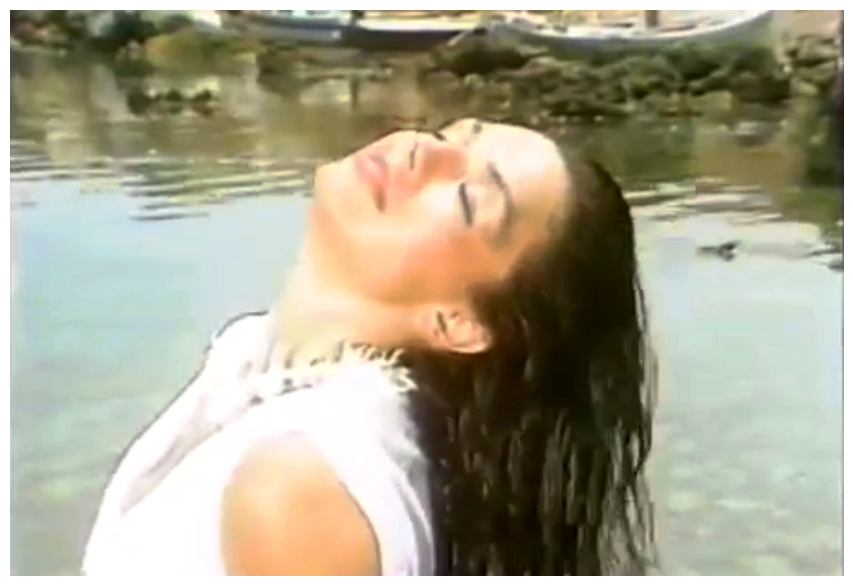

Figure 3 - Still from Gorgona (1987).

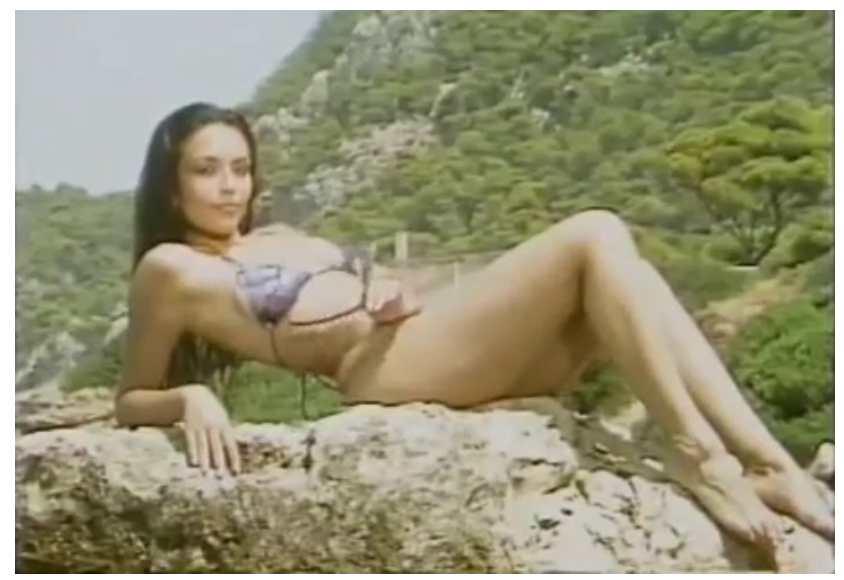

Figure 4 - Still from Gorgona (1987).

In addition, as twice mentioned in Gorgona, Marina often sits motionless on a rock for hours, gazing at the sea, like her late father, a seaman who, after getting sick because of his underwater activities, was doomed to spend the rest of his life on land. Marina's relationship with her father replays the Jungian Elektra complex of the collective mermaid archetype: the girl's fixation on her father, before directing her desire to a man outside her family (Hayward, 2017: 26). Marina's mother is absent both in the diegesis and her recollections. In contrast, Marina speaks fondly of her father, cherishes her memories of him, and, by studying archaeology, fulfills his dream of her recovering the undersea treasure that he had discovered. Like her father, and like many fictional mermaids, Marina is visually connected to this underwater world/town; she swims around it or spends her time near it, thinking of the people, the ruins, the buildings and the statues that were absorbed by the sea. And like a mermaid she reveals her father's underwater world to her new object of desire, whom she saves from drowning with the kiss of life (Figure 5), a 
situation evoking modern culture's most famous mermaid story: Hans Christian Andersen's (1907: 7; Hayward, 2017).

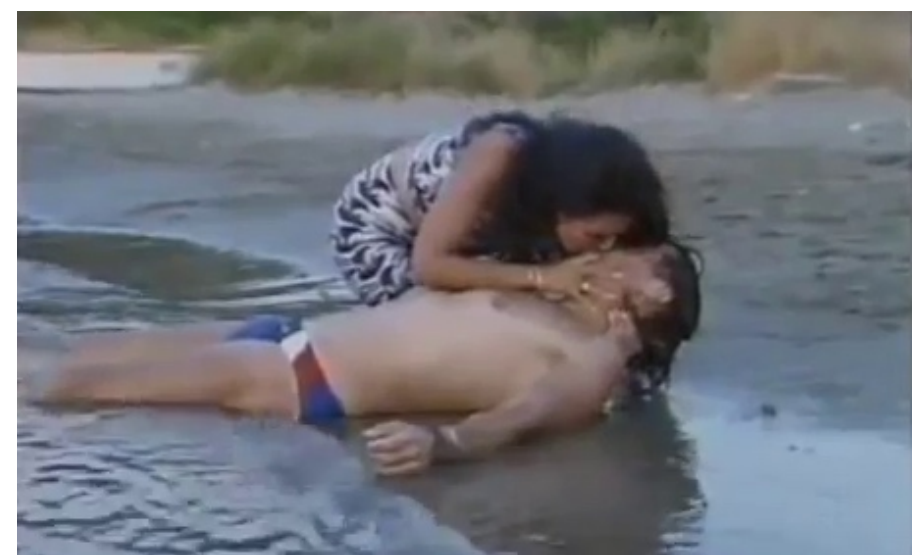

Figure 5 - Still of rescue scene from Gorgona (1987).

Gorgona's climactic reference to a mermaid comes towards the film's end. One night in his usual bar in Athens, Petros has the following conversation with the bartender:

Petros: Do you know the legend of the yopyóva?

The bartender: A little...

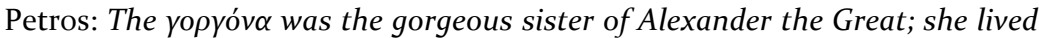
in the waves and when she met sailors, she would ask them if King Alexander was alive.

The bartender: That's right, now I remember.

Petros: But this is the fable, right? The true story is different.

The bartender: Do you know it?

Petros: Yes, because I met her.

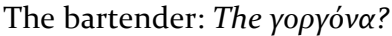

Petros: Yes. She is a magical woman who lives in the sea and gathers all the beauty and the light of the Aegean.

The bartender: But she is half-fish.

Petros: She is a real woman. But a magical one, because she lives in the beautiful realm of the sea. The sailors lost their minds when they saw her.

This exchange ties together all previous references to a mermaid, connecting them to the story of Alexander the Great's sister while adapting it. In Petros' and this video-film's account, the $\gamma о \rho \gamma o ́ v \alpha$ is a real woman, with no tail and apparently not vindictive. As she proves in the course of the film, she literally saves a man's life and metaphorically gets him to reform. In another revision of the Alexander legend, the man to whom this yopyóv $\alpha$ is connected is not an invincible king but a fugitive who sells ancient replicas. At the end of the film, we learn that his real name is Alexis (short for Alexander). At the same time, this updated mermaid retains her legendary appeal to seamen and the Greek origins of Alexander's fictional sister. She lives in the Aegean Sea, personifying its light and beauty. Not surprisingly, she possesses the characteristically attractive Mediterranean tanned, 
curvy body, dark eyes and hair, as emphasised on the cover of the video tape (Figure 6), which Filini's star image was largely based on.

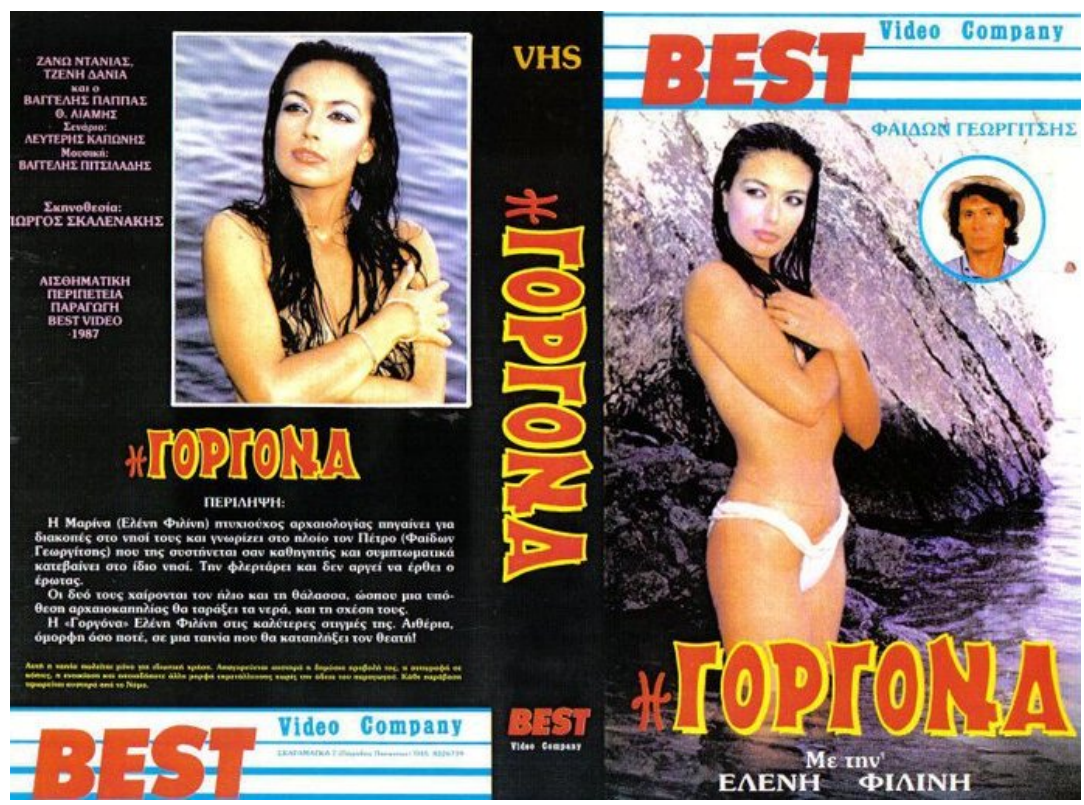

Figure 6 - Cover of video release version of Gorgona (1987).

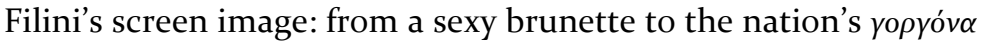

The decline of Greece's studio system after the early 1970 caused a discontinuity in the establishment of significant new Greek film stars. As a result, the video film industry of the 1980 os needed to produce new stars, who could cater to its predominately lower and middle-class audience ${ }^{11}$ and encompass what critics consider the major components of film stars: a signification of important ideological contradictions (Dyer, 1979) and a mythic quality (Morin, 1961). The industry sought to create such a female star in Filini, who within the few years of video films' popularity developed from a typical sexy brunette to modern

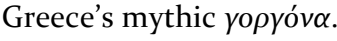

Filini started her film career in the late 1970s. By the mid-1980s she had appeared in many films of different kind (comedies, satires and dramas), most often in supporting roles that had her in revealing or close-fitting clothes or lingerie. Cast as a belly dancer (Jack o kavallaris, Dimis Dadiras, 1979), a show girl (O palavos kosmos tou Thanasi, Dinos Katsouridis, 1979), a maid turned into a sex instructor (Sexokynigos, Dimis Dadiras, 1981), or a female recruit dressed in hot shorts and disguised as a gypsy girl (Oi fantarines, Dimis Dadiras, 1979), Filini became known for her curvaceous body and long, black hair and was also featured on the covers of many of that time's popular magazines.

In 1985 Filini began starring in direct-to-video films and within three years she appeared in about 15 such films. Although there was some variety in her roles, most likely due to the

\footnotetext{
${ }^{11}$ For the audience of the Greek video films, see Kassaveti (2016).
} 
need of product differentiation in the context of massive video production, certain traits were attached to her screen persona, leading to a rather complex star image. Always psychically tempting, she often played a simple working girl from an ordinary, middle-class family. She was shown openly expressing interest in a man and talking about sex but having a permanent relationship in mind. She enjoyed life, dancing provocatively in discos or singing, while being exceptionally dynamic: she might be a black belt in karate, a car mechanic, a passionate advocate of women's rights, or a fearless journalist. Her star image succeeded in merging contradictory traits that simultaneously evoked the typical sex symbol of media industry, the principled girl of middle-class ideology, and the independent woman whom Greek feminism promoted and the Panhellenic Socialist Movement (PASOK) of Andreas Papandreou embraced after assuming government in $1981 .{ }^{12}$

Before Gorgona, a couple of video-films had opened the way for combining these traits of

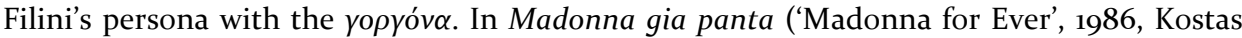
Bakodimos), she is simply characterised as yopyóv $\alpha$ thanks to her good looks and talent as a dancer. In Flyfitzouri ('Lollipop', 1985), the central male character compares her to the fictional creature. As they sit on the beach one evening, while a romantic soundtrack is

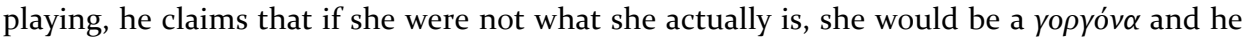
would be a merman. By merging Filini's star characteristics with those deriving from the fictional mermaid, Skalenakis' Gorgona completed Filini's connection to the mythical figure. Virtually all traits of Filini's previous screen persona are present in this video-film. She falls for a man and offers to have sex with him but wants a steady relationship with him. She is devoted to a demanding discipline - archaeology - and takes risks to help her beloved, while showing off her body. Next to these traits, this video-film's many allusions to a mermaid elevate her image to a mythical status. They also add to it an aura of national

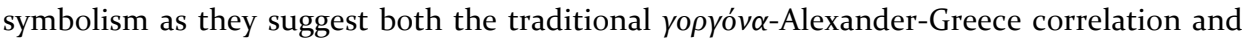
the 1980s' Greek popular emphasis on indigenous, brunette, female beauty.

In Gorgona, Marina's tall, shapely body is the first thing that Petros notices about her while onboard to her island, and the camera follows his gaze from her feet up. From that moment on, Marina's swimming and mermaid-like reclining on rocks or onshore allow the camera and the spectator to admire her body. Moreover, following a trend in modern

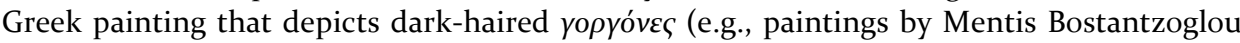
[Bost], Nikolaos Christopoulos, Tasos Zografos, and anonymous folk artists) Gorgona presents its modern version of mermaid with long black hair. It thus conforms to a tendency in the Greek media of the 1980s, when female beauty was associated with dark features (like Vana Barba, another Greek celebrity of the time), ${ }^{13}$ and both builds upon and sexualises the image of another brunette who had been associated with a mermaid in Greek audiovisual media (although, again, not represented onscreen in fishtailed form), Maria Tzompanaki (b. 1956), the star of the popular TV mini-series To gymno koritsi, ('The naked girl' - E.R.T. Channel, 1982, Francis Carabott, in six episodes).

Broadcast in 1983, To gymno koritsi adapted the eponymous 1962 novel by Nikos Athanasiadis (1904-1990) to state TV. The novel and the TV series focus on the liaison between a middle-class young man and Angela, a young woman from the island of Lesvos. The villagers consider Angela a mermaid, and she claims that when in the sea her body is

12 PASOK institutionalised some feminist demands, with "a landmark in the evolution of gender equality legislation" the Family Law reform of 1983 (Davaki, 2013: 6).

${ }^{13}$ Filini's beauty, in particular, was (and still is) described in the Greek press and media as "classical Mediterranean" or "classical Greek." 
covered by scales, her legs merge into a fishtail, and her hands turn into fins (Athanasiadis, 1964: 59). ${ }^{14}$ She knows the secrets of the sea depths, disappears into the ocean for long periods - especially at night - swims like a fish, and has an erotic relationship with a male dolphin that the young man kills. ${ }^{15} \mathrm{~A}$ symbol of humankind's instinctual sexual origins, Angela is described by Athanasiadis as a bronze creature with long, raven hair and black eyes (1964: 31, 51-53, 74, 156), a description which found its 1980s' TV personification in actor Tzompanaki, known for her 'Mediterranean features' (e.g., Giatzoglou, 2020). Skalenakis' Gorgona distances itself from the self-conscious artistic depth and symbolic weight of Athanasiadis' work, which were also present in the TV adaptation but both Gorgona and the TV adaptation of To gymno koritsi shared the 1980s' Greek appraisal of alluring brunettes and both were made at a time when audiovisual revisions of old legends seemed possible under the transformative climate of the 1980 os Greece. ${ }^{16}$

While building on the beauty discourse of To gymno koritsi, and of Greece in the 1980s, Gorgona challenges the Anglo-Saxon blondness and sweetness with which the mermaid had been associated in the commercially successful American film Splash (1984, Ron Howard). Splash influenced film, video and TV production from North America, Europe, and Australia (Hayward, 2017) to India, China, South Korea, and Philippines (Hayward 2018a; 2018b; Hayward and Wang, 2018; Keith and Lee, 2018). Splash was released in Greece in September 1984 as I Gorgona ('The Mermaid'). Indeed, one could argue that Gorgona would not have been possible without Splash. ${ }^{17}$ As if responding to the Americanisation of the archetype, Greek video production created its own version of a mermaid: instead of Madison (played by Daryl Hannah), a blond, blue-eyed, and slim mermaid in Splash, the Greek video-film offered a dark, curvaceous Mediterranean woman; ${ }^{18}$ and to Splash's rather unsophisticated Madison, Gorgona replied with a smart, dynamic, and educated woman, consistent with Filini's image after 1985. Gorgona symbolically brought the global fictional creature's aquatic quality to the dynamic world of its heroine, presented at the beginning and end of the film through the fountain at the University of Athens.

\footnotetext{
${ }^{14}$ In the diegesis of the novel and the TV series, Angela is never depicted turning into a mermaid. This metamorphosis is only described secondhand. In addition, the novel and the TV series end with Angela lost for good after the male dolphin's death; a female dolphin regularly approaches the ships of the area, rumored to be Angela transformed and looking for the murderer of her beloved male dolphin.

${ }^{15}$ Athanasiadis' novel has been translated into English, French, Spanish, German, and other languages. Shortly after the Greek TV adaptation, Philippe Muy made his directorial debut with a French film adaptation of Athanasiadis' novel under the title L'arbre sous la mer ('The tree under the sea', 1985).

${ }^{16}$ In the 1980 oudiovisual Greek production, a different revision of the Greek mermaid legend also took place in the film $O$ drakoulas ton Exarcheion ('Dracula of Exarcheia', 1983, Nikos Zervos). In a scene of this loosely structured, parodic, cult film that ridicules abundant aspects of modern Greek life and culture, a secondary male character appears as a merman lying onshore and asking an old man on a pedalo boat if the Music Brigades (the provocative Greek band playing in the film) are still alive; the old man replies that he is simply a refugee from Tashkent, looking for the way to Cythera. This scene parodies the legend about Alexander the Great and his mermaid sister (and its nationalist connotations) as well as the established art cinema of Theodoros Angelopoulos, whose Taxidi sta Kythira ('Voyage to Cythera', 1984), about a political refugee from Tashkent, was then under production.

${ }^{17}$ Advanced publicity concerning Disney's preparation of the animated The Little Mermaid (1989, Ron Clements and John Musker) perhaps also played a role in the conception of Gorgona.

${ }^{18}$ This ideological stance seems to be in accord with Skalenakis' interests, who in the 196os put forth the idea of a "national" film musical, reacting against that time's Greek musical of an "American kind" (Papadimitriou, 2006: 87-89; 2012: 153).
} 
Marina's association with Greece's oldest university, the Aegean Sea, and a Greek landscape featuring idyllic bays and picturesque boats, as well as her dark features and the references to Alexander's sister, work together to promote Gorgona's multi-faceted mermaid as Greek and to re-substantiate the $\gamma$ o $\rho$ óv $\alpha$-Greece analogy that had permeated folk and artistic Greek culture since the 17th Century. Marina's specialisation - archaeology - and her underwater activities related to the ancient town further link her to Greece and its past and

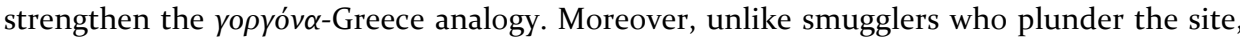
Marina's plan is to obtain government funding to bring artefacts to the surface. The

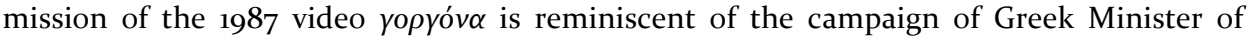
Culture Melina Merkuri for the return of the Parthenon Marbles (also known as the Elgin Marbles) from London to Greece, with a pivotal moment in this campaign being Merkuri's impassioned speech to the Oxford Union in 1986, where she described these marbles "the essence of Greekness." ${ }^{\prime 19}$ This understanding of Gorgona's heroine - and star, Filini - as an updated personification of the nation's yopyóv $\alpha$ is perhaps nowhere more evident than in a little-known artwork by Ntinos Petratos, a contemporary popular Greek artist, painter, set and costume designer. In this work, Petratos digitally produced an image of Marina/Filini floating in the sea with a fishtail, wearing two gold snake armbands of the ancient Hellenistic period and a 17th Century Cycladic folk earring with pendant caravels, alongside the head of the famous ancient sculpture held at the National Archaeological Museum in Athens that is believed to represent Zeus or Poseidon (Figure 7).

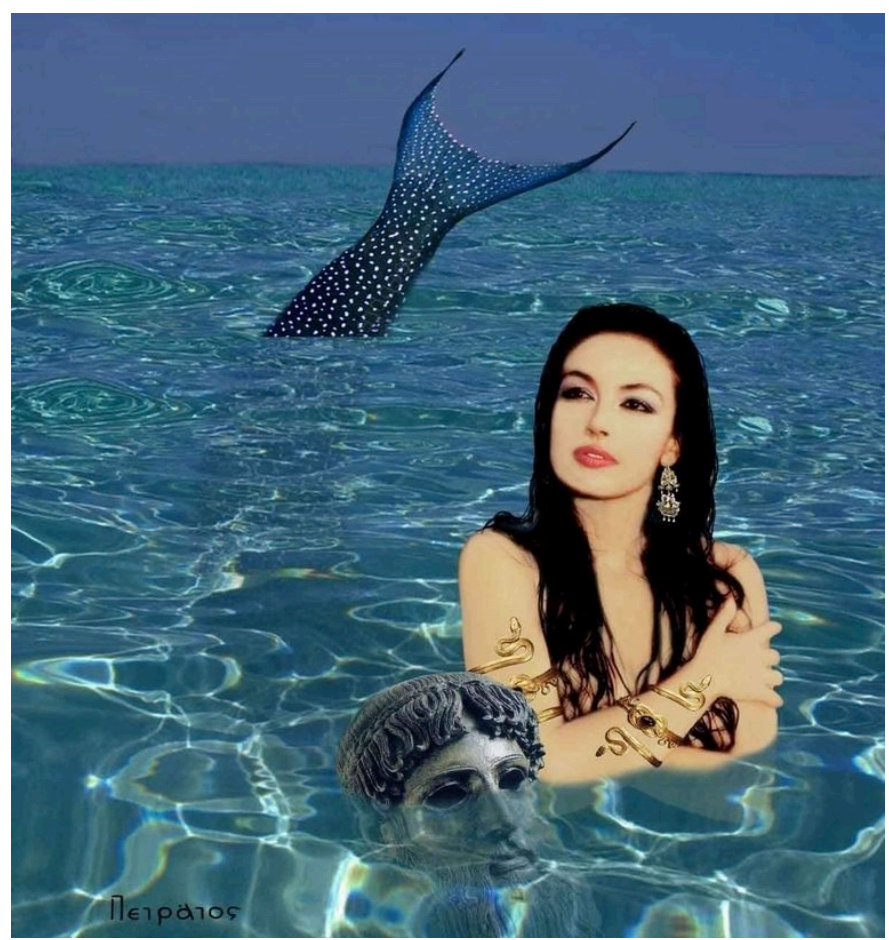

Figure 7 - Gorgona artwork inspired by the eponymous film, Ntinos Petratos (n.d.)

\footnotetext{
${ }^{19}$ For such uses of antiquity in modern Greek popular culture more broadly, see Yalouri (2014).
} 


\section{Conclusion}

Skalenakis' Gorgona revises a national folk legend and borrows the universal traits of the mermaid to promote Greek video-film's ideal woman and foremost star, Filini. Gorgona's mermaid combines Mediterranean beauty, intelligence, dynamism, moral integrity, and the ability to save men and lives in a country of ancient treasures and idyllic aquatic areas. One could hardly argue that among the dozens of direct-to-video Greek works in the late 198os, one such work, Gorgona, played a key role in the reconceptualization of mermaids in Greece. ${ }^{20}$ Gorgona seems to have some lasting effect only in connection to its female star. In the 8o Greek Cult Film Festival in January 2010 in Athens, where Filini received a prize, Gorgona was one of her two video-films screened; and recently, a picture of her in her sixties posing in a swimming suit brought memories of Gorgona to social discourse (e.g. Mcteam, 2019).

Despite its rather limited contribution to the public imagination on mermaids, Skalenakis' Gorgona is important for several reasons. It corroborates the "polyvalence" (Hayward, 2017: 188) of the mermaid concept, used in this case as a star vehicle and a response to the foreign popular imagery of mermaid/female beauty. It suggests the tension between the Americanisation and subsequent globalisation of the mermaid figure after the mid-1980s and a country's deep-rooted symbol of the mermaid. And it brings forth the importance of a local mermaid tradition, so closely linked to a nation's imagery that its media industry cannot but consider it. In the 1980s, this media industry evoked and revised this tradition to counter a foreign trend and promote a contemporary Greek-looking mermaid and screen star. The Greek media industry had to wait another 20 years before it would construct new popular mermaid images, that would have a different approach to foreign mermaids and the national mermaid legend. In 2007-2008, in a Greek social and cultural context that goes beyond the scope of this article, Mega Channel, one of Greece's most powerful private TV channels, broadcast Gorgones, a fantasy/comedy/romance series in 24 episodes. The series' two female protagonists were mermaids who grew legs and had adventures on land. One blond and one a redhead, they looked like Madison in Splash and Ariel in Disney's The Little Mermaid respectively. ${ }^{21}$ In episodes 9 and 10, Alexander's sister also appeared as a comic character. Excessively erotic, she turned from a yo $\rho \gamma o$ v $\alpha$ to a woman, dressed in folk costume. This updated, comic version of Alexander's sister of the 21st Century Greece was told that her brother had died, and she grieved for all those seamen that she killed when they replied to her that Alexander the Great was no longer alive.

\section{BIBLIOGRAPHY}

Adikimenaki, M (2004) I eikonografisi ton ellinikon paradosiakon paramythion, PhD dissertation, Department of Early Childhood Education, Thessaloniki: Aristotle University of Thessaloniki

Aggelopoulos, P (2014) Filologikes meletes kai ponimata, Athens: Anatolikos

\footnotetext{
${ }^{20}$ Unlike the Greek films of the 1950s-1970s, the video-films of the 1980 os are rarely re-run on Greek TV channels, falling thus into oblivion.

${ }^{21}$ Full of anachronisms and references to other popular works, Gorgones once mentions Splash.
} 
Andersen, H.C (1907) Fairy tales from Hans Christian Andersen illustrated by the Brothers Robinson (edited by Rhys, E), Edinburgh: Turnbull and Spears

Anonymous (1987) 'Erxetai i Gorgona', Video Express 2oth August: 7

Antoniou, Ch (1981) O kosmos tis gorgonas. Themata kai morfes tis laikis paradosis sto ergo tou Seferi (ermineutiki proseggisi), Athens: E.L.I.A.

Athanasiadis, N (1964) To gymno koritsi, Athens: Alvin Redman (Hellas)

Bacchilega, C and Brown, M.A (2019) (eds) The Penguin book of mermaids, New York: Penguin Publishing Group

Chatzidakis, G (2001) 'Sta pelaga tis logotechnias kai tis poiisis', I Kathimerini, Epta imeres 15th July: 21-25

Davaki, K (2013) The policy of gender equality in Greece, Brussels: Policy Department C: Citizens' Rights and Constitutional Affairs, European Parliament, https://www.europarl.europa.eu/RegData/etudes/note/join/2013/493028/IPOL-

FEMM_NT(2013)493028_EN.pdf - accessed 9th July 2021

Dyer, R (1979) Stars, London: British Film Institute

Giatzoglou, F (2020) 'Flashback: otan i Maria Tzompanaki protagonistouse sto Gymno koritsi 38 chronia prin - to klik sto Instagram', Bovary 22nd September: https://www.bovary.gr/faces/my-best/h-maria-tzompanaki-otan-epaize-sto-gymno-koritsi - accessed 5th June 2021

Hayward, P (2017) Making a splash: mermaids (and mermen) in 2oth and 21st century audiovisual media, New Barnet: John Libbey and Co/Indiana University Press

Hayward, P (2018a) 'Changelings, conformity and difference: Dyesebel and the sirena in Filipino popular culture' in Hayward, P (ed) Scaled for success: the internationalisation of the mermaid, New Barnet: John Libbey and Co/Indiana University Press: 107-128

Hayward P (2018b) 'Matsya Fabulism: Hindu mythologies, mermaids and syncretism in India and Thailand' in Hayward, P (ed) Scaled for success: the internationalisation of the mermaid, New Barnet: John Libbey and Co/Indiana University Press: 21-50

Hayward, P (2018c) 'Mermaids, Mercultures and the Aquapelagic Imaginary', Shima v12 n2: 1-11

Hayward, P and Wang, P (2018) 'Millennial měirényú: mermaids in 21st century Chinese culture', in Hayward, P (ed) Scaled for success: the internationalisation of the mermaid, New Barnet: John Libbey and Co/Indiana University Press: 129-147

Hopman, M G (2012) Scylla: myth, metaphor, paradox, Cambridge: Cambridge University Press

Kamilaki, E (2001) 'Mythoi kai laikes paradoseis', I Kathimerini, Epta imeres 15th July: 8-13 
Karkavitsas, A (1994/1899) 'I Gorgona', in Xagoraris, N (ed) Logia tis ploris, Athens: Grammata: 16o-164

Kassaveti, U-H (2014) I elliniki videotainia (1985-199o): Eidologikes, koinonikes kai politismikes diastaseis, Athens: Asini

Kassaveti, U-H (2016) 'Audio-visual Consumption in the Greek VHS era: social mobility, privatization and the VCR audiences in the 1980s', in Kornetis, K, Kotsovili E, and Papadogiannis, N (eds), Consumption and gender in southern Europe since the long 196os, London and New York: Bloomsbury: 241-256

Kassaveti, U-H (2017) 'From glory to decline and back again: notes on the Greek popular film and direct-to-video musicals of the 1980s', Filmicon n4: 56-82: http://filmiconjournal.com/journal/article/pdf/2017/4/4 - accessed 5th June 2021

Keith, S and Lee, S-A (2018) 'Legend of the blue sea: mermaids in South Korean folklore and popular culture', in Hayward, P (ed) Scaled for success: the internationalisation of the mermaid, New Barnet: John Libbey and Co/Indiana University Press: 69-88

Kounenaki, P (2001) 'Gorgona. H mythiki adelfi tou Megalexandrou' I Kathimerini, Epta imeres 15th July: 2-3

Mcteam (2019) 'H Eleni Filini pozarei me magio kai thymizei tin tainia tis I gorgona. I ithopoios einai pio kalligrammi apo pote' Marie Claire 2oth August: https://www.marieclaire.gr/celebrities/h-eleni-filini-pozari-magio-ke-thymizi-tin-tenia-tisgorgona/ - accessed 5th June 2021

Mitakidou, S, Manna, A L, and Kanatsouli, M (2002) 'Alexander the Great and the mermaid', Folktales from Greece: A Treasure of Delights, Greenwood Village: Libraries Unlimited: 93-95

Morin, E (1961) The stars: an account of the star-system in motion pictures, London: Evergreen Books

Myrivilis, S (1987/1955) I Panagia i Gorgona, Athens: Vivliopoleion tis Estias

Papadimitriou, L (2006) The Greek film musical: a critical and cultural history, Jefferson, and London: McFarland \& Co

Papadimitriou, L (2012) 'Music, dance and cultural identity in the Greek film musical', in Papadimitriou, L and Tzioumakis, Y (eds), Greek cinema: texts, histories, identities, Bristol and Chicago: Intellect: 149-166

Pavlikianis, K (2014) 'Vaggelis Pitsiladis: synentefxi ston Konstantino Pavlikiani', MusicHeaven 2nd October:

https://www.musicheaven.gr $/ \mathrm{html} /$ modules.php?name=News\&file=article\&id=4284 accessed 5th June 2021

Politis, G.N (1878) 'Neoelliniki mythologia: Enalioi daimones, Gorgona', Parnassos n2: 259275 
Syropoulos, S (2018) A bestiary of monsters in Greek mythology, Oxford: Archaeopress Publishing Ltd

Tentorio, G (2013) 'H gorgona tou Seferi: Laografiko motivo kai poiitiko prattein', in Vozikas, G (ed) Laikos politismos kai entechnos logos (poiisi - pezografia theatro), Conference Proceedings (Athens, 8-12th December 2010), Athens: Akademia Athinon: 487-502

Triantafyllou, M (2020) 'Fyta kai zoa sto elliniko laiko paramythi: Oi sxeseis tous me ton anthropo', PhD Dissertation, Department of Education Sciences in Early Childhood, School of Education Sciences, Democritus University of Thrace, Alexandroupoli

Yalouri, E (2014) 'Possessing antiquity: reconnecting to the past in the Greek present', in Tziovas, D (ed), Re-imaging the past: antiquity and modern Greek culture, Oxford: Oxford University Press: 165-185

Zora, P (1960) ‘I gorgona eis tin ellinikin laikin technin', Parnassos v2 n3: 331-365 